ievietošanas kompostē̌anas kamerā. Vidējās izdalītās siltuma jaudas kompostu maisijumiem 3...12 dienu kompostēšanas periodiem uzrādītas tabulä.

Tabula

Vidējā izdalītā kompostēšanas silltuma jauda, W uz $1 \mathrm{~kg}$ sausnes

\begin{tabular}{|c|c|c|c|c|}
\hline $\begin{array}{c}\text { Laika periods, } \\
\text { dienas }\end{array}$ & Ezeru niedres & Zāle & $\begin{array}{c}\text { Komposts, } \\
\text { nostrādāts 75\% } \\
\text { niedres 25\% }\end{array}$ & $\begin{array}{c}\text { Niedres 80\%+ } \\
\text { kütsmēsli 20\% }\end{array}$ \\
\hline $0-3$ & 5,8 & 18,7 & 3,1 & 6,8 \\
\hline $0-6$ & 8,1 & 10,4 & 3 & 5,7 \\
\hline $0-12$ & 7,8 & $\mathrm{n}$ & $\mathrm{n}$ & $\mathrm{n}$ \\
\hline $0-18$ & 4,7 & $\mathrm{n}$ & $\mathrm{n}$ & $\mathrm{n}$ \\
\hline
\end{tabular}

\title{
Secinājumi
}

1. Mehanizäcijas līdzekḷu modernizēšana un kompostēšanas operāciju vienkāršošana samazina tehnologiju energoietilpỉbu par $21 \%$.

2. Vidējo siltuma jaudu lielumi rāda, ka niedru kompostiem, salīdzinot ar zāḷu kompostu, vidējā siltuma izdalīšanās intensitāte pirmo sešu kompostēšanas dienu periòdā ir 3 reizes mazāka.

3. Zālu komposta maksimālā izdalītā jauda $31 \mathrm{~W}$ tika noverota otrajā dienā, bet niedru kompostam $12 \mathrm{~W}$ tika novërota 5 . dienā pēc kompostēšanas uzsākšanas.

4. Komposta maisỉjumu pārjaukšana un slāpekḷa minerālmēslu papildināšana palielina siltumu jaudu visiem novērotajiem kompostu paraugiem.

\section{THE PROBLEMS ON ESTIMATION OF THE RATE OF SUSTAINABILITY}

\author{
TINA RANDLA, RAIVO VILU \\ Tallinn Technical University, Chair of Biochemistry, \\ Ehitajate tee 5, Tallinn, 19086, Estonia \\ Phone: 3726202805 , Fax: 3726202020
}

Launching of the sustainable development means solving quantitative problems of controlling of the state of global circulations, functioning of climate machine etc. The main processes determining sustainability of the state of the natural environment are

a) carbon cycle and the work of the climate machine which in fact are closely connected,

b) water cycle, (over)use and pollution of global and regional water resources,

c) also the change of the flow of organic substance and biogenic elements into one-way flow "land $\rightarrow$ town" instead of the natural circulation "soil $\rightarrow$ plant $\rightarrow$ animal (human) $\rightarrow$ soil".

To ensure the sustainable development human activities must not jeopardize the dynamic balance of the main substance cycles (especially carbon and water cycles) exceed the buffering capacity of natural systems. This presumes the quantitative assessments of the processes that influence the sustainability of the development and the 
distribution of the buffering capacity between people (determination of the environmental space) which does not mean only the execution of the "division operation", but also the existence of the will of the people to commit themselves to worked-out division rules. The people's good will should be based on the understanding, on the integrated and systematized, presented in an understandable manner, information and the availability of it.

In Estonia the sustainable development is endangered mostly by the concentration of industrial production and, as a result of it, also the consumption of natural resources (especially water) and environment pollution in Northeast of Estonia, which represents about $7 \%$ of the geographical area of the country and where nearly one third of Estonian industry, primarily oil shale mining and processing, is concentrated. The environmental problems caused directly by oil shale industry, are covered $11 \%$ of the territory of the district, but the problems related with overconsumption and pollution of water and emission of $\mathrm{CO}_{2}$ by oil shale burning overspread the borders of the district.

The aim of present study is to discuss main problems affecting the sustainability of the natural environmental systems in their entirety, considering both local (Ida-Viru district and Estonia), regional (the Baltic Sea catchment are) and global pecularities. The quantitative descriptions of global and Estonian carbon and water cycles will be given. Environmental space and the ecological footprint will be defined and shown how to calculate them. An overview of legal and economic mechanisms developed for the regulation of carbon and water cycles will be given $\left(\mathrm{CO}_{2}\right.$-tax, etc.), relevant calculating algorithms will be given. The development problems of Estonian oil shale energetics from the point of view of quantitative indicators of sustainability and also throuh prism will be presented. In the frame of the study the quantitative assessment principles will be dealt both on global and local (the catchment area of the Baltic Sea, Estonia and regions) levels showing the interdependences of the problems encountered at different levels. As great environmental problems in Estonia are concentrated in Ida-Virumaa, a special attention will be drawn to the oil shale mining and energetics.

\title{
ДЕСЯТЬ ЛЕТ ПЛАТНОГО ПРИРОДОПОЛЬЗОВАНИЯ В ЭСТОНИИ
}

\author{
ЭНHО РEЙHCAJTY \\ Таллинский Технический Университет, Горный институт, \\ Копли 82, Таллинн 10412, ЭСТОНИЯ
}

С конца восьмидесятых годов в Эстонии действует система платежей за пользование природными ресурсами. Ввод системы поставил перед собой задачу сократить эксплуатацию минеральных ресурсов и ограничить загрязнение природной среды. Платежи были установлены на добычу полезных ископаемых, выкачивание вод, спуск сточных вод в водоемы, загрязнение воздуха и складирование отходов. Все перечисленные виды платежей автор трактует как единую систему платного природопользования. Ведь по существу, также как ресурсом горной промышленности является полезное ископаемое, так и водоемы и атмосфера, куда выбрасываются отходы, можно рассматривать как промышленное звено производства. Иными 